\title{
Standardization or Stigmatization? Challenges Confronting Lexicography and Terminography in Sesotho sa Leboa*
}

\author{
V.M. Mojela, Sesotho sa Leboa National Lexicography Unit, University of \\ Limpopo, Turfloop Campus, Polokwane, Republic of South Africa
}

(mojelav@ul.ac.za)

\begin{abstract}
The article investigates the effects of the underutilization of the abundant vocabulary of Sesotho sa Leboa, which results from a one-sided standardization approach owing to the disregard and stigmatization of most dialects. Sesotho sa Leboa has several dialects differing greatly concerning terminology, pronunciation and vocabulary. The situation is complicated and aggravated by a standardization which has sidelined more than half of the dialects because of factors such as the influence of colonialism and lack of government co-ordination, the missionary activities, and the influence of early writers and publications. The strict and narrow standardization of Sesotho sa Leboa resulted in the exclusion of large parts of the dialectal vocabulary, the forcing of dialect speakers to accept a foreign standard language, the creation of 'prestige' and 'inferior' dialects, the separation of the standard language from its own dialects and the awakening of a nationalistic spirit among some dialect-speaking communities. Finally solutions for the challenges caused by these developments are afforded.
\end{abstract}

Keywords: COLONIALISM, CORPUS, DIALECT, INFERIOR DIALECTS, LEMMATIZATION, LEXICOGRAPHY, MISSIONARY ACTIVITIES, NATIONALISM, ORTHOGRAPHY, PRESTIGE DIALECTS, STANDARD LANGUAGE, STANDARD DICTIONARY, SIDELINED DIALECTS, STIGMATIZED DIALECTS, TERMINOGRAPHY

Opsomming: Standaardisasie of stigmatisasie? Uitdagings waarvoor leksikografie en terminografie in Sesotho sa Leboa te staan kom. Die artikel ondersoek die uitwerking van die onderbenutting van die ryk woordeskat van Sesotho sa Leboa wat volg uit 'n eensydige standaardisasiebenadering deur die miskenning en stigmatisasie van die meeste dialekte. Sesotho sa Leboa het verskeie dialekte wat sterk verskil ten opsigte van terminologie, uitspraak en woordeskat. Die situasie word gekompliseer en vererger deur 'n standaardisasie wat meer as die helfte van die dialekte gesylyn het vanweë faktore soos die invloed van kolonialisme en die ontbreking van regeringsamewerking, die sendingaktiwiteite, en die invloed van vroeëre skrywers en publikasies. Die streng en eng standaardisasie van Sesotho se Leboa het gelei

This article was presented as a keynote address at the Twelfth International Conference of the African Association for Lexicography, organized by the Tshwane University of Technology in collaboration with the IsiNdebele National Lexicography Unit, at the Soshanguve Campus, Pretoria, Republic of South Africa, 27-29 June 2007. 
tot die uitsluiting van groot dele van die dialektiese woordeskat, die dwang van dialeksprekers om 'n vreemde standaardtaal te aanvaar, die totstandkoming van "invloedryke" en "ondergeskikte" dialekte, die skeiding van die standaardtaal van sy eie dialekte, en die opwekking van 'n nasionalistiese gees by sommige van die dialeksprekende gemeenskappe. Laastens word oplossings aangebied vir die uitdagings veroorsaak deur hierdie ontwikkelinge.

Sleutelwoorde: KOLONIALISME, KORPUS, DIALEK, ONDERGESKIKTE DIALEKTE, LEMMATISERING, LEKSIKOGRAFIE, SENDINGAKTIWITEITE, NASIONALISME, ORTOGRAFIE, INVLOEDRYKE DIALEKTE, STANDAARDTAAL, STANDAARDWOORDEBOEK, GESYLYNDE DIALEKTE, GESTIGMATISEERDE DIALEKTE, TERMINOGRAFIE

\section{Introduction}

Sesotho sa Leboa or Northern Sotho is one of the 11 official languages of the Republic of South Africa. It consists of around 27 dialects (Mokgokong 1966: 89), with the following among the major ones: Sekone, Sepedi, Seroka, Selobedu, Sepulana, Sethlokwa, Sekopa, Sehananwa, Sekgaga and Sephalaborwa. Only a few of these dialects are represented in the official standard language, i.e. Sekone, Sepedi, Sekopa, Sekgaga (of Mphahlele), and the dialects around Turfloop and Chuenespoort. The majority of the dialects contributed very little to the development of standard Sesotho sa Leboa with regard to vocabulary and structure. The dialects which were sidelined by standardization include, among others, dialects such as Seroka, Selobedu, Sepulana, Sethlokwa, Sehananwa, Sekgaga (of Maake) and Sephalaborwa, which border with the VatsongaMachangane and the Venda communities in the Lowveld and the northern part of the Limpopo Province. The authorities who initially developed standard Sesotho sa Leboa did not have an interest in these dialects because they regarded them to be too 'inferior' and too 'primitive' for use in developing the standard language. The reason for this was that these dialects were regarded as 'corrupt' versions of the 'prestige' dialects and standard Sesotho sa Leboa. The type of attitude which was adopted by the standardizing authorities towards these sidelined dialects is comparable to the following description of dialect by Allen and Linn (1986: 220):

This represents perfectly the idea of dialect and most of the connotations that surround the idea: a dialect is uncouth - an ugly, imperfect, corrupt version of the language which I myself speak perfectly.

\section{Factors which facilitated the stigmatization of these dialects}

The stigmatization of the majority of the dialects of Sesotho sa Leboa can be ascribed to factors such as the influence of colonialism and lack of government co-ordination, the missionary activities and their role in the standardization of Sesotho sa Leboa, and the influence of early writers and publications. 


\subsection{The influence of colonialism and lack of government co-ordination}

The governments which ruled over South Africa during the late 19th and the early 20th centuries, i.e. at first those of the British in the Cape Colony and Natal, and the two Boer Republics of the Transvaal and the Orange Free State, and subsequently that of the Union after 1910, paid little attention to the development of education and the development of the languages of the indigenous South African communities.

Unlike the colonial rule which intervened to guide the standardization of languages like Kiswahili in the former East African Federation (Kenya, Uganda and Tanzania), and Shona in the former Rhodesia, the politicians in South Africa left the responsibilities of developing the indigenous education and the indigenous languages to the European missionaries. When explaining the influential role political authorities have in the standardization of languages, Mojela (1999: 20) cites the following example from the formation and the standardization of Shona:

It was the Government of Southern Rhodesia which took the initiative to appoint Clement Doke in 1929 to investigate and report to the Legislative Assembly on the possibility of unifying the dialects of the territory into a literary form for official and educational purposes and the standardization of the orthography.

It was only after 1929 that the Transvaal Education Department (TED) started making attempts at standardizing the Sotho languages in the former Transvaal which eventually led to the formation of the Language Boards (Mojela 2005: 46). In South Africa, for instance, it was only after the passing of the Bantu Education Act in October 1953 (Act No. 47 of 1953) that the South African government took over control of formal education from the missionaries. Even though the Bantu Education Act gave government power to establish the Language Boards to develop the indigenous languages, the missionary legacies still dominated the system, because the elite group who came to dominate the membership of the Language Committees and the Language Boards were still the same products of missionary education. As such, the Language Committees and the Language Boards continued to promote the dialects and the languages favoured by missionary policies.

\subsubsection{The missionary activities}

The development of the Northern Sotho orthography and the origin of its standard form were very much influenced by the work of the German missionaries in Sekhukhuneland. Karl Endemann (1836-1919) of the Berlin Evangelical Missionary Society came to South Africa in 1860 and established several missionary stations in Bopedi and Maleuskop between 1862 and 1867. In 1865 Endemann founded the Botšhabelo Missionary Station on the banks of the Olifants River (near the present Loskop Dam) which became an important education 
centre for the Basotho ba Leboa communities (Mojela 1997: 13). His colleagues and successors included missionaries like Alexander Merensky, Hermann Wangemann, Heinrich Grützner, and Albert Nachtigal. The first Sesotho sa Leboa dialects the German missionaries learned to speak and convert to writing were the Sekopa and Sepedi dialects. Other Northern Sotho dialects did not have this missionary advantage since their areas had little, or no missionary activity.

These missionaries started developing orthographies in Sepedi and Seko$\mathrm{pa}$, and translating the Bible and many religious publications into these dialects. These publications were meant to be used for the education of and communication with the indigenous Bapedi and Bakopa communities in order to teach them the Word of God. The Botšhabelo mission station, for instance, became an important education centre which provided for the development of 'Sepedi'.

The Sepedi publications produced through translations of biblical material and early missionary research were to be used as references in the future standardization of the language. The German missionaries in Bopedi did not regard Sepedi as a dialect of any language because they were unaware of Seroka, Selobedu, Sepulana, Sethlokwa, Sehananwa and Sephalaborwa. Many parents from areas such as Mapulaneng, Bolobedu and Botokwa sent their children to study at Botšhabelo where they were taught in Sepedi.

Even though few missionary stations were later established in other parts of the former Transvaal, they did not pay much attention to the development of dialects, but relied on the publications produced in Bopedi. Mission stations like Medingen (Mmidinyene) in Bolobedu and Metz (Mmetse) in Makhutšwe did little to develop Sesotho sa Leboa dialects in their areas.

\subsubsection{The role of the missionary activities in the standardization of Sesotho sa Leboa}

The missionaries promoted the dialect or dialects in the areas where they operated.

The first Sesotho sa Leboa orthography by the German missionaries was in the Sepedi dialect. This elevated Sepedi to a superior status. The sidelined Sesotho sa Leboa dialects did not have these missionary orthographies, proving what Allen and Linn (1986: 218) say about dialect:

The idea that a language for which there exists no written form, a language which has not yet been alphabetized, is for that reason intrinsically inferior, not a real language, but a mere dialect.

The establishment of schools, tertiary institutions and health facilities at the missionary stations created 'mini-urban centres' in the rural areas which came to be regarded as places of civilization. Therefore, the dialects spoken in these areas became representative of civilization. Botšhabelo was one of these mini- 
urban centres for the Bapedi communities.

Moreover, orthographies, publications and written materials were produced at these mission stations, and these would influence the future course of standardization in favour of the dialects of the communities in the vicinities of the missionary stations.

Lack of missionary activities in the Lowveld and the northern part of the former Transvaal compelled parents there to send their children to places such as Botšhabelo to receive education, thereby helping to promote the Sepedi and Sekopa dialects at the expense of their own dialects. After graduating from Botšhabelo, most of these young 'elite' group returned to places like Bolovedu, Botlokwa, Senwabarwana, Makhutšwe (or Makhutšu) and Mapulaneng, speaking the 'language of civilization', i.e. Sepedi. Using Sepedi was to them a status symbol, while their own dialects were associated with illiteracy and inferiority.

As a result of the missionary legacy, the real standardization of Sesotho sa Leboa, which started during the 20th century, tended to be dominated by the Sepedi and Sekopa dialects - a dominance which sidelined most of the Sesotho sa Leboa dialects and which later came to be challenged by the Sekone dialect.

\subsection{The influence of early writers and publications}

Most of the young graduates from education centres like Botšhabelo, Emmarentia Geldenhuys Secondary School, Kilnerton College and Bethesda, who were not Bapedi, started abandoning the Botšhabelo orthographies and shifting to Sekone and the dialects around the present Polokwane and Mokopane. The pressure exerted by Sepedi was gradually reduced by the rise of early scholars and writers like Dr M.J. Madiba and other new generation writers who gradually distanced themselves from the Botšhabelo orthographies. Dr Madiba, who was himself of Ndebele origin, published the famous Mahlontebe series of school readers which was prescribed in primary schools from substandard A to standard 6. Just like Dr A.S.V. Barnes's Afrikaans and English series, i.e. 'Die Môreson-reeks' and 'The New Graded English Series', Madiba's Mahlontebe series dominated Northern Sotho Education for almost a quarter of a century since the early sixties of the 20th century.

The Mahlontebe series was based on the Sekone dialect and, from the mid 20th century, these booklets practically came to represent standard Northern Sotho, especially after the newly established Northern Sotho Language Board started compiling an official orthography and standardizing the language basing it on Madiba's orthography. The introduction of the Northern Sotho Language Board, for instance, came at a time when there were several missionary orthographies in Sepedi, Sekopa and Sekone, with little, or no written forms in the majority of the dialects of Sesotho sa Leboa.

When standardizing this language the Language Board used existing missionary and secular orthographies, the latter being those resulting from the 
work of scholars like Dr M.J. Madiba and Mr O.K. Matsepe. In a special research study made by translating a one-page paragraph into a few major dialects of Sesotho sa Leboa, the results revealed a major reduction in the role of Sepedi in the official standard language approved by the first Northern Sotho Language Board. The dialectal contribution to standard Sesotho sa Leboa today can be analyzed as follows (citing only a few major dialects):

$\begin{array}{lrlr}\text { Sekone } & 50 \% & \text { Sepedi } & 30 \% \\ \text { Selobedu } & 2 \% & \text { Sethlokwa } & 8 \% \\ \text { Seroka } & 2 \% & \text { Sepulana } & 1 \%\end{array}$

The remaining dialects constitute $7 \%$.

\section{The standardization resulted in a stigmatization}

Rather than being the development of a standard language, the standardization of Sesotho sa Leboa was more a 'cleaning and purifying of the language', a 'keeping the language clean and pure by sifting out inferior and dirty elements from the dialects' and a 'purifying of the language by excluding impure and corrupt versions'. The consequences of this strict and narrow type of standardization for Sesotho sa Leboa are, among others, the following:

\subsection{The exclusion of large parts of the dialectal vocabulary}

Almost two-thirds of the vocabulary of the language is stigmatized, being excluded from the standardized version. The rich vocabularies of the sidelined dialects which were supposed to be included in dictionaries and used in literary works are omitted from the standard language because (it is assumed) this inferior vocabulary will spoil the purity of the language. For instance, an extensive part of the vocabulary of Seroka, Selobedu, Sepulana, Sethlokwa, Sehanawa and Sephalaborwa is excluded from the standard language. To those who developed Sesotho sa Leboa the inclusion of these dialects into the standard language seems to have been a mistake. Thus, in order to keep the standard language as pure as possible, these 'inferior' dialects had to be excluded from the language. Before 1994, there was not a single scholar who showed interest in developing orthographies for these stigmatized dialects - not even the speakers of these dialects themselves.

\subsection{The forcing of dialectal speakers to accept a foreign standard language}

The majority of the dialect-speaking communities are forced to accept the standard language which is not only practically foreign, but also totally different from their mother dialects. This proved to be a provocation to the spirit of 
nationalism and a danger to the stability of the Sesotho sa Leboa standard language. The communities from the sidelined dialects were made to believe that their dialects are inferior to those which are much closer to the standard language. Most of the speakers of these dialects were, and still are wary of speaking their 'languages' in public for fear of being stigmatized themselves. The standard Sesotho sa Leboa, which is taught in schools in, among others, Bolobedu, Bothlokwa, Bokgaga, Senwabarwana and Mapulaneng, differ completely from the indigenous dialects spoken in these areas. In fact, the Sesotho sa Leboa standard language is more of a second language than a mother tongue to these communities.

\subsection{The creation of 'prestige' and 'inferior' dialects}

The prestige dialects are the dialects which were consulted or used to develop the standard language. This led to the elevation of these dialects to a superior status while the status of the dialects which were sidelined by standardization remain inferior, being stigmatized as low-class dialects. The speakers of the prestige dialects see no need of knowing or speaking the inferior dialects because (they assume) they will gain nothing from these dialects. On the other hand, the communities whose dialects have been downgraded to an inferior position, strive to know, understand, read and write the standard language, including the dialects closer to the standard language in order to elevate their status. Of course, this is a natural phenomenon, i.e. that people whose language has status or prestige speak only their language, while people whose language has lower or inferior status or prestige speak all the languages. In South Africa, for instance, almost all the indigenous communities can speak English, while from the English communities only a tiny section is able to utter even a phrase in one of the nine indigenous languages, the reason being that the English do not see any need of knowing the 'inferior' indigenous languages, while on the other hand the indigenous communities want to associate themselves with the status of English. This is also the case with the prestige dialects versus the inferior, low-class, stigmatized dialects of Sesotho sa Leboa. In most cases, the speakers of the prestige dialects of Sesotho sa Leboa would need an interpreter to understand the inferior dialects, while the speakers of these dialects usually communicate effectively in all the dialects of Sesotho sa Leboa. The Balobedu people understand all that is said in Sepedi, Sekone, Sekopa and all the dialects of Sesotho sa Leboa, while the Bakone and Bapedi will need interpreters to understand what the Mapulana and Balobedu say. Most speakers of the prestige dialects of Sesotho sa Leboa will need to have the following Lobedu expression explained:

- Mola khaawe o ya khata (Lobedu)

- Moja sa gagze o ya iphihla (standard Sesotho sa Leboa) 
- Literal meaning: a person who eats his/her food hides him-/herself, a person who eats his/her food doesn't want to be seen

- Meaning: you shouldn't tell other people about your fortunes

\subsection{The separation of standard Sesotho sa Leboa from its own dialects}

Standard Sesotho sa Leboa is much closer to Setswana and the Sesotho languages than to dialects like Seroka, Selobedu, Sepulana, Sethlokwa and Sephalaborwa. The following comparison of Selobedu (a Sesotho sa Leboa dialect), Setswana (an official language) and standard Sesotho sa Leboa, explains this fact:

$\begin{array}{llll}\text { Sesotho sa Leboa } & \text { Setswana } & \text { Selobedu } & \text { English } \\ \text { mopani } & \text { nato/mopani } & \text { mothanare } & \text { mopani tree } \\ \text { leribiši } & \text { lerubisi } & \text { mmankhoto } & \text { owl } \\ \text { mmankgagane } & \text { mmamanthane } & \text { molema } & \text { bat } \\ \text { hlapi } & \text { thapi } & \text { khobe } & \text { fish } \\ \text { betha/itiya } & \text { betsa } & \text { motha/tiya } & \text { wallop } \\ \text { legotlo } & \text { legotlo } & \text { lehoto/peba/mantoro } & \text { mouse } \\ \text { legapu } & \text { legapu } & \text { lesalabu } & \text { watermelon } \\ \text { nona } & \text { nona } & \text { kholophana } & \text { be fat/gain weight } \\ \text { mogaditswane } & \text { mogaditswane } & \text { mphekwa } & \text { lizard } \\ \text { bogobe } & \text { bogobe } & \text { booswa } & \text { porridge } \\ \text { kota } & \text { kota } & \text { mothate } & \text { wooden pole } \\ \text { bolela } & \text { bua } & \text { apa/bolabola } & \text { talk } \\ \text { natefa } & \text { natefa } & \text { tefa } & \text { sweet/tasty } \\ \text { molete } & \text { mosima } & \text { moina } & \text { hole }\end{array}$

These examples prove that Setswana can to a greater extent be considered a dialect of Sesotho sa Leboa (and vice versa) than Selobedu. This is also true of the Sesotho language. As such, the standardization of Sesotho sa Leboa has not only created a huge difference between the standard language and its own dialects, but has also brought it closer to other independent national languages which were supposed to be further apart from its dialects.

\subsection{The awakening of a nationalistic spirit among the Balobedu and Ma- pulana communities}

The one-sided standardization of Sesotho sa Leboa did not only stigmatize the majority of its dialects, but also encouraged the rise of a nationalistic feeling among the speakers of these so-called inferior dialects. The appearance of the name 'Sepedi' instead of 'Sesotho sa Leboa' in the 1996 Constitution of the Republic of South Africa (section 6.1) gave an impetus to the Balobedu and Mapulana to start demanding official status for their 'languages' (dialects). 
These communities developed a spirit implying that if Sepedi can gain official status, so can Selobedu and Sepulana. The reaction from the Balobedu emerged immediately after the publication of the Constitution in 1996, as shown in the following statement of Archbishop Prince Madlakadlaka, chairperson of the Khelobedu Project in the Sowetan of 11 January 2007:

He said that the Khelovedu project started in 1996 after children complained that teachers prohibited them from speaking or writing in their home language. 'We launched the Khelovedu project, (which includes) members of the Modjadji royal family and the parents of the pupils.'

\subsubsection{The developments among the Mapulana communities}

The Mapulana communities, just like the Balobedu, are developing an orthography for their 'language' Sepulana. They started questioning the validity of the incorporation of Sepulana into standard Sesotho sa Leboa, which is now referred to as Sepedi in the 1996 Constitution. Knowing that Sepedi, just like Sepulana, is one of the dialects of Sesotho sa Leboa, the Mapulana people found it unacceptable that, by using the name 'Sepedi' for 'Sesotho sa Leboa', their 'language' Sepulana is now considered a dialect of Sepedi. In 2002, the Sepulana Language Development Committee wrote a submission to the Joint Constitutional Review Committee requesting a constitutional amendment which gives official status to Sepulana. The Joint Constitutional Review Committee transferred its submission to PanSALB for investigation, which in turn gave this assignment to the Sesotho sa Leboa National Language Body. This language body found the main cause for this demand to be the sidelining and the 'stigmatization' of the Sepulana dialect and the replacement of the name of the standard language Sesotho sa Leboa by Sepedi in the new Constitution of the Republic of South Africa. Consequently, the Sesotho sa Leboa National Language Body recommended to PanSALB to seek the reinstatement of the name 'Sesotho sa Leboa' in order to reunite the Basotho ba Leboa communities.

\subsubsection{The reaction of the Balobedu community after 1994}

About the Balobedu regarding their language, Boshego (2002: 1) says:

Some of the Balobedu (Valobedu) suggested that their language, Khelovedu, should not only be given due consideration but be included as an official South African language. They also suggested that it should be used as a medium of instruction in their schools.

However, these suggestions were not taken into consideration. Instead Selobedu together with Sekone, Seroka, Sepulana, Setlokwa, Sekopa, Sehananwa, Sekgaga and Sephalaborwa was, according to Section 6.1 (Founding Provisions) of the Constitution of the Republic of South Africa, 1996, to become dia- 
lects of Sepedi (Boshego 2002: 1). When the then President of the Republic of South Africa, Dr Nelson Mandela, visited Her Majesty Queen Modjadji V at Khetrakoni (the Balobedu Palace) on 23 February 1999 she requested him to consider the recognition of Selobedu as 12th official language. The Sowetan of 24 February 1999 reported as follows in this regard:

The Queen told Mandela that her language, Selobedu, was not officially recognized and her people were forced to be taught Sepedi, which is not their language.

The Balobedu, under the influence of the ideas of the Kara Heritage Institute of Dr Mathole Motshekga and the Balobedu community leaders like Archbishop Prince Madlakadlaka, are demanding a withdrawal from standard Sesotho sa Leboa (or 'Sepedi' as it is called in the Constitution) and the recognition of Selobedu (or 'Khelovedu' as they themselves call it) as official language. Archbishop Prince Madlakadlaka and the Balobedu communities have already written several submissions and memoranda to the Constitutional Court, the various Government Departments and PanSALB, demanding recognition of official status for their 'language' Khelovedu. At the beginning of 2007, Archbishop Prince Madlakadlaka was quoted in an article entitled 'Another Official Language' in the Sowetan of 11 January 2007, referring to 'Sepedi' (the name used by the Department of Education for 'Sesotho sa Leboa') as too foreign to the Balobedu learners. To the Archbishop, Sepedi is the main cause for the high failure rate of Balobedu learners in schools. When writing examinations, Balobedu learners are compelled to translate from their mother tongue (Selobedu) into a foreign language (Sepedi).

The Sowetan of 11 January 2007 also quotes a Lobedu learner who has failed the standard 10 examination, as saying:

I failed because I could not write or speak Sepedi very well. I could not finish writing my scripts during the exams. This is because I was translating Khelovedu into Sepedi, which takes more time. Thanks to the Department (of Education) and PanSALB for making it difficult for us to make it in school.

\section{The challenges for Sesotho sa Leboa lexicography}

As point of departure, the Sesotho sa Leboa National Lexicography Unit started writing the Comprehensive Monolingual Dictionary and the Bilingual Sesotho sa Leboa/English Dictionary in 2001, basing the research on the Sesotho sa Leboa Corpus which was compiled at the University of Pretoria under the leadership of the lexicographer and metalexicographer Prof D.J. Prinsloo, head of the Department of African Languages. The first volumes of these two dictionaries have already been published. The first volume of the Sesotho sa Leboa/ English Bilingual Dictionary appeared with Maskew Miller Longman in May 2006, while the first volume of the Comprehensive Monolingual Sesotho sa Leboa 
Dictionary was published by Nutrend Publishers in 2007. The fact that these newly published dictionaries are based on the already established corpus means that the stigmatized lexical items from the sidelined Sesotho sa Leboa dialects did not form part of the lemmatization in these dictionaries. The Sesotho sa Leboa lexicographers are faced with the major challenge of bridging the gap between the standard language and the sidelined, stigmatized dialects in order to make the standard language acceptable to all the communities by:

(a) doing a thorough research into all the dialects, especially the sidelined dialects, in order to have a record of the complete potential vocabulary of Sesotho sa Leboa,

(b) including all the stigmatized lexical items from the sidelined, stigmatized dialects of Sesotho sa Leboa in the already established corpus,

(c) lemmatizing and subsequently standardizing the lexical items from all the stigmatized dialects in order to make Sesotho sa Leboa acceptable to all the Basotho ba Leboa communities, and

(d) lemmatizing and subsequently including these lemmata in the dictionaries as variants for most of the standard lexical items of Sesotho sa Leboa.

\section{Conclusion}

It is important to realize that the lemmatization of the vocabulary of the stigmatized dialects of Sesotho sa Leboa will not only bridge the gap between the prestige dialects and the stigmatized dialects, but will also guarantee the unity and the stability of Sesotho sa Leboa which was endangered during the 20th century by the language authorities. The lemmatization and the subsequent standardization of the stigmatized dialects will not only unite the Basotho ba Leboa communities under one standard language, but will also increase the size of the lexicon of Sesotho sa Leboa extensively.

\section{References}

Allen, H.B. and M.D. Linn (Eds.). 1986. Dialect and Language Variation. London/Montreal: Academic Press/Harcourt Brace Jovanovich Publishers.

Boshego, P.L. 2002. Is Khelovedu a Language or a Dialect? PanSALB Occasional Papers 8. PanSALB.

Mojela, V.M. 1997. The Development of Bantu Linguistics. NSOT300 Study Guide. Pietersburg: University of the North.

Mojela, V.M. 1999. Prestige Terminology and its Consequences in the Development of Northern Sotho Vocabulary. Unpublished D.Litt. et Phil. Thesis. Pretoria: University of South Africa.

Mojela, V.M. 2005. Standardization and the Development of Orthography in Sesotho sa Leboa A Historical Overview. Webb, V. The Standardization of African Languages in South Africa. Pretoria: University of Pretoria. 
Mokgokong, P.C. 1966. A Dialect-geographical Survey of the Phonology of the Northern Sotho Area. Unpublished M.A. Dissertation. Pretoria: University of South Africa.

\section{Newspapers}

Sowetan, 24 February 1999.

Sowetan, 11 January 2007.

\section{Constitution, Reports and Acts}

The Constitution of the Republic of South Africa, Act 108 of 1996. 